\title{
Bacterial production rates and concentrations of organic carbon at the end of the growing season in the Greenland Sea
}

\author{
Knut Yngve Børsheim* \\ Department of Biotechnology, The Norwegian University of Science and Technology, 7491 Trondheim, Norway
}

\begin{abstract}
Profiles from the euphotic zone at the end of July in the Greenland Sea showed that bacterial production rates were highest in surface Arctic domain water, and generally lower in locations from the warmer North Atlantic domain. Bacterial production from all locations investigated averaged $0.26 \mu \mathrm{M} \mathrm{C} \mathrm{d}^{-1}$ in the upper $50 \mathrm{~m}$ water column, and the 0 to $50 \mathrm{~m}$ integrated bacterial production averaged $67 \%$ of the 0 to $500 \mathrm{~m}$ integrated production. Both bacterial total counts and growth rates were high compared to other oligotrophic open ocean areas. In the upper $50 \mathrm{~m}$ water column, bacterial total counts averaged $1.1 \times 10^{6}$ cells $\mathrm{ml}^{-1}$, and bacterial growth rate averaged $0.68 \mathrm{~d}^{-1}$ The high bacterial growth rate and production rate may be related to the fact that at the end of the productive season considerable amounts of annually produced transient organic material were present. The amount of organic material that had accumulated through the productive season was estimated by comparing profiles of TOC measured at the end of July with winter values, and with values of TOC from $1000 \mathrm{~m}$ depth and below. The amount of transient TOC in the upper $50 \mathrm{~m}$ averaged $1.15 \mathrm{~mol} \mathrm{C} \mathrm{m}^{-2}$, and ranged from 0.68 to $1.5 \mathrm{~mol} \mathrm{C} \mathrm{m} \mathrm{C}^{-2}$ Based on an assumed bacterial growth yield of $30 \%$, the measured bacterial production rates in the upper $50 \mathrm{~m}$ inferred a turnover of the transient TOC in the range of 8 to $91 \mathrm{~d}$.
\end{abstract}

KEY WORDS: Bacterial production - TOC $\cdot$ DOC $\cdot$ Greenland Sea $\cdot$ Carbon cycle

\section{INTRODUCTION}

In the biogeochemical cycling of carbon in the ocean, heterotrophic bacteria are the principal consumers of dissolved organic carbon (DOC), and consequently bacterial respiration is a major process in the mineralization of organic carbon. In Arctic oceanic regions, such as the Greenland Sea, information on heterotrophic activity is scarce. From a transect over the Polar Ocean, Wheeler et al. (1996) reported that this region is far from barren, despite perennially cold waters and ice cover. Moreover they were able to show that the turnover of transient DOC in July/August was between 3 and 12 mo as calculated from estimates of bacterial production rates and DOC measurements. In the Chukchi Sea, which is situated at a similar latitude as the cruise reported in the present study, moderately

\footnotetext{
•E-mail: borsheim@chembio.ntnu.no
}

high rates of bacterial production at the end of the growing season have been found (Cota et al. 1996, Wheeler et al. 1996, Rich et al. 1997). Similar studies have not previously been reported from the Greenland Sea.

The Central Greeniand Sea is an area where deep water formation takes place, and this process is involved in sequestering of anthropogenic atmospheric $\mathrm{CO}_{2}$ (Broecker \& Peng 1992, Anderson et al. 2000). The flux of carbon from dissolved inorganic carbon (DIC) to organic material via photosynthesis is an important part of the carbon dynamics of the ocean surface, and primary production with subsequent accumulation of DOC represent processes that favour diffusion of $\mathrm{CO}_{2}$ from the atmosphere to the ocean (Siegenthaler \& Sarmiento 1993). Current information on DOC concentrations in the euphotic zone of the oceans suggests that annual transient DOC represents a large pool of material. At $66^{\circ} \mathrm{N}$ in the Norwegian Sea, such transient DOC found at the end of the growing season rep- 
resented an amount of material corresponding to $20-50 \%$ of current estimates of primary production for the area, varying among 3 years between 1.6 and $4.2 \mathrm{~mol} \mathrm{C} \mathrm{m}^{-2}$ (Børsheim \& Myklestad 1997). In the Ligurian Sea, the summer accumulation was estimated at $1 \mathrm{~mol} \mathrm{C} \mathrm{m}^{-2}$ (Copin-Montégut \& Avril 1993), and in the Sargasso Sea the corresponding estimate was $1.2 \mathrm{~mol}$ $\mathrm{C} \mathrm{m}^{-2}$ in 1992/93 (Carlson et al. 1994). Estimates from the Equatorial Pacific Ocean suggest that an average of $20 \%$ of new primary production accumulates in this area (Hansell et al. 1997), and the corresponding estimate from Ross Sea polynya was 10 to $20 \%$ (Hansell \& Carlson 1998a). Comparable rates of accumulation have also been observed in coastal areas (Williams 1995, AlvarezSalgedo et al. 1999, Børsheim et al. 1999).

After the productive season, DOC concentrations gradually return to winter values, which in the areas investigated were close to deep water values. It is presently unclear whether this decline is brought about mainly by physical mixing of surface water with water from below the euphotic zone, which presumably has a rather constant content of mainly refractory DOC (Carlson \& Ducklow 1996), or if the decline is dominated by bacterial degradation in the surface waters. It is of interest to know the contribution of each of these processes for the evaluation of the role of DOC in the total carbon cycle of these open ocean areas.

Here I report bacterial production rates measured at the end of the productive season to estimate heterotrophic consumption rate of DOC at various depths, along with estimates of transient total organic carbon (TOC). The present study forms part of a larger program including measurement of primary production and sedimentation, along with inorganic carbon flux measurements, physical oceanography and modelling (European Subpolar Ocean program). The overall aim of the program is to evaluate the capacity of the Greenland Sea for the transport of $\mathrm{CO}_{2}$ from the atmosphere to the ocean's interior.

\section{MATERIALS AND METHODS}

Seawater samples were collected in acid-cleaned Niskin bottles connected to a CTD-rosette. Table 1 shows the positions sampled and number of samples processed.

Bacterial total counts were measured using epifluorescence microscopy after staining with DAPI (Porter \& Feig 1980). Samples were fixed with $2.5 \%$ glutaralde-

Table 1. Overview of the locations sampled and variables measured in the Norwegian and Greenland Seas. Samples for winter and deep water TOC were collected in 1995 from RV 'Håkon Mosby', the University of Bergen, Norway. Samples from the end of the growing season were from RV 'Johan Hjort' (Institute of Marine Research, Bergen, Norway, cruise no. 1996210). Number of samples is given within parentheses

\begin{tabular}{|c|c|c|c|c|}
\hline \multirow[t]{2}{*}{ Date; position } & \multirow[t]{2}{*}{ Stn } & \multicolumn{3}{|c|}{ Depth interval (m) } \\
\hline & & $\begin{array}{c}\text { Bacterial } \\
\text { production }\end{array}$ & $\begin{array}{l}\text { Bacterial } \\
\text { total count }\end{array}$ & TOC \\
\hline Feb $25 ; 75^{\circ} \mathrm{N}, 7^{\circ} 1.1^{\prime} \mathrm{W}$ & & & & $10-3300(19)$ \\
\hline Feb $27 ; 75^{\circ} \mathrm{N}, 3^{\circ} \mathrm{W}$ & & & & $10-3500(23)$ \\
\hline $\operatorname{Mar} 2 ; 75^{\circ} \mathrm{N}, 0^{\circ} \mathrm{W}$ & & & & $800-3520(11)$ \\
\hline $\operatorname{Mar} 3 ; 75^{\circ} \mathrm{N}, 5^{\circ} \mathrm{E}$ & & & & $20-3000(12)$ \\
\hline Jul $22 ; 70^{\circ} 45.04^{\prime} \mathrm{N}, 07^{\circ} 00.15^{\prime} \mathrm{E}$ & A & $10-500(7)$ & $10-500(9)$ & $10-1000(12)$ \\
\hline Jul $22 ; 71^{\circ} 05.19^{\prime} \mathrm{N}, 05^{\circ} 49.42^{\prime} \mathrm{E}$ & $\mathrm{B}$ & & & $1-3031(35)$ \\
\hline Jul $23 ; 72^{\circ} 04.68^{\prime} \mathrm{N}, 02^{\circ} 14.75^{\prime} \mathrm{E}$ & $\mathrm{C}$ & $1-198(7)$ & $1-198(7)$ & $1-500(22)$ \\
\hline Jul $23 ; 72^{\circ} 23.80^{\prime} \mathrm{N}, 01^{\circ} 8.69^{\prime} \mathrm{E}$ & $\mathrm{D}$ & $10-73(6)$ & $10-73(6)$ & $1-40020)$ \\
\hline Jul $24 ; 73^{\circ} 26.21^{\prime} \mathrm{N}, 02^{\circ} 13.14^{\prime} \mathrm{W}$ & $E$ & $2-400(4)$ & $2-400(4)$ & $2-600(24)$ \\
\hline Jul $25 ; 74^{\circ} 59.54^{\prime} \mathrm{N}, 08^{\circ} 13.65^{\prime} \mathrm{W}$ & $\mathrm{F}$ & $1-60(8)$ & $1-60(8)$ & $11-1000(12)$ \\
\hline Jul $26 ; 74^{\circ} 59.90^{\prime} \mathrm{N}, 04^{\circ} 58.79^{\prime} \mathrm{W}$ & G & & & $9-1000(12)$ \\
\hline Jul $26 ; 75^{\circ} 00.12^{\prime} \mathrm{N}, 02^{\circ} 57.50^{\prime} \mathrm{W}$ & $\mathrm{H}$ & & & $10-1000(12)$ \\
\hline Jul $26 ; 74^{\circ} 59.99^{\prime} \mathrm{N}, 00^{\circ} 08.79^{\prime} \mathrm{W}$ & I & $10-500(3)$ & $10-500(3)$ & $10-1000(12)$ \\
\hline Jul $27 ; 75^{\circ} 00.01^{\prime} \mathrm{N}, 00^{\circ} 00.08^{\prime} \mathrm{E}$ & $\mathrm{J}$ & $5-50(4)$ & $5-50(4)$ & \\
\hline Jul $27 ; 75^{\circ} 00.92^{\prime} \mathrm{N}, 02^{\circ} 58.66^{\prime} \mathrm{E}$ & $\mathrm{K}$ & $5-300(5)$ & & \\
\hline Jul $28 ; 75^{\circ} 00.25^{\prime} N_{1} 06^{\circ} 59.58^{\prime} \mathrm{E}$ & $L$ & $2.5-14.7(5)$ & $2.5-147(5)$ & \\
\hline Jul $28 ; 74^{\circ} 59.53^{\prime} \mathrm{N}, 10^{\circ} 58.94^{\prime} \mathrm{E}$ & M & $2.5-147(5)$ & $2.5-147(5)$ & \\
\hline Jul $29 ; 75^{\circ} 00.48^{\prime} N, 14^{\circ} 53.64^{\prime} \mathrm{E}$ & $\mathrm{N}$ & $10-400(5)$ & $10-400(5)$ & \\
\hline Jul $31 ; 74^{\circ} 30.63^{\prime} \mathrm{N}, 06^{\circ} 57.87^{\prime} \mathrm{E}$ & $\mathrm{O}$ & $10-36(5)$ & $10-36(5)$ & \\
\hline Jul $31_{i} 74^{\circ} 31.03^{\prime} \mathrm{N}, 06^{\circ} 57.87^{\prime} \mathrm{E}$ & $P$ & $5-36(5)$ & & $5-501(12)$ \\
\hline Aug $1 ; 74^{\circ} 29.96^{\prime} \mathrm{N}, 04^{\circ} 55.56^{\prime} \mathrm{E}$ & $\mathrm{Q}$ & $5.6-65(5)$ & $5.6-65(5)$ & \\
\hline Aug $1 ; 74^{\circ} 30.07^{\prime} \mathrm{N}, 03^{\circ} 55.74^{\prime} \mathrm{E}$ & $\mathrm{R}$ & & & $5.6-500(11)$ \\
\hline Aug $2 ; 72^{\circ} 46.93^{\prime} \mathrm{N}, 07^{\circ} 15.99^{\prime} \mathrm{E}$ & S & $4.4-501(5)$ & $4.4-501(5)$ & \\
\hline
\end{tabular}


hyde (final concentration), and all samples were filtered within $6 \mathrm{~h}$ onto $0.2 \mu \mathrm{m}$ pore size Nuclepore filters, stained, mounted and frozen. The preparations were kept frozen until they could be counted 2 to 3 mo later using a Zeiss Axioplan with a HBO 50W mercury lamp and filter set 487902 for epifluorescence microscopy.

Bacterial production was measured by the ${ }^{3} \mathrm{H}$ [methyl]-thymidine method (Fuhrman \& Azam 1980, 1982). Tritiated thymidine with a specific activity of 3.1 TBq mmol ${ }^{-1}$ (Du Pont New England Nuclear, USA) was added to a final concentration of $12 \mathrm{nM}$. Samples were incubated in $10 \mathrm{ml}$ Nunc minisorb tubes at in situ temperature in the dark for 45 to $90 \mathrm{~min}$. The incubations were stopped by filtering on $0.2 \mu \mathrm{m}$ pore size Nuclepore filters, followed by washing with $3.3 \mathrm{ml}$ ice-cold TCA directly on the filter (Børsheim 1990). Radioactivity was quantified using Filtercount (Packard) and a Packard Tri Carb scintillation counter. Bacterial production was calculated assuming a yield of $0.023 \mu \mathrm{g} \mathrm{C}$ (pmol thymidine $)^{-1}$, which is the median of conversion factors used in open ocean water studies reviewed by Ducklow \& Carlson (1992). This corresponds to a thymidine to cell production conversion factor of $2.0 \times 10^{18}$ (bacterial cells) (mol thymidine incorporated $)^{-1}$ and an average cell biomass of $11.5 \mathrm{fg}$ $\mathrm{C}$ cell $^{-1}$. Specific growth rates $(\mu)$ were calculated as the ratio (cell production):(total count).

Care was taken to incubate the thymidine incorporation experiments close to in situ temperature. This was obtained using a preformed thermostated gradient with 12 temperatures from -2 to $8^{\circ} \mathrm{C}$, with 3 replicate incubation sites for each temperature. From the recorded temperature at sampling, depths were selected which had temperatures corresponding to a temperature fixed in the preformed gradient, within $0.2^{\circ} \mathrm{C}$ and usually closer. For each station investigated 5 to 7 depths were selected, except at Stns $O$ and $P$, where 301 Go Flow bottles were used and only 3 depths were sampled.

Samples for TOC were collected in $7.5 \mathrm{ml}$ Supelco vials with Teflon-lined caps (Bellefonte, Pennsylvania, USA), and frozen. TOC was measured with the high temperature catalytic combustion technique (Suzuki et al. 1992, Sharp et al. 1993), using a Dohrmann DC 190 analyzer as previously described (Børsheim \& Myklestad 1997). After acidification to $\mathrm{pH} \mathrm{2,} \mathrm{the} \mathrm{samples}$ were sparged with pure oxygen for $4 \mathrm{~min}$ to remove inorganic carbon. From each vial five $200 \mu \mathrm{l}$ aliquots were injected by an autosampler that collected aliquotes directly from the Supelco vials. To eliminate or minimize carryover effects, a Milli-Q blank was placed between every seawater sample. For reasons still unclear, the reading from the first injection was normally higher than from the following injection, regardless of the concentration of the previous sample. Therefore the result from the first injection was routinely discarded. During the specific period when the samples reported here were run, the Milli-Q reading was on average $14 \mu \mathrm{M} \mathrm{C}(\mathrm{SD}=4.3$ ). However, in earlier and later periods, the Milli- $Q$ readings were lower, which we assume is due to the presence of DOC in the Milli$Q$. These values have therefore not been used as a blank to be subtracted from sample readings. Much lower blank readings were obtained when analyzing a blank reference standard received from J. Sharp, University of Delaware, USA, as part of an international standardization experiment for DOC determination (Sharp 1997). This blank, denoted Q+, gave $7.1 \mu \mathrm{M} \mathrm{C}$, which has been subtracted from all measurements.

Integrated values from profiles were calculated using trapezoid interpolation between each depth sampled.

\section{RESULTS}

Bacterial production in the upper $50 \mathrm{~m}$ at Stns $\mathrm{A}, \mathrm{C}$ and $D$ was $7.1,10.9$ and $9.8 \mathrm{mmol} C \mathrm{~m}^{-2} \mathrm{~d}^{-1}$ respectively (Fig. 1). Stns A and C had warm surface temperatures characteristic of the Atlantic domain. Both Stns $C$ and D are located over Mohn's Ridge, where the Arctic front is formed, but only the salinity and temperature profiles of Stn D showed characteristics indicating the presence of the Arctic front (Swift \&

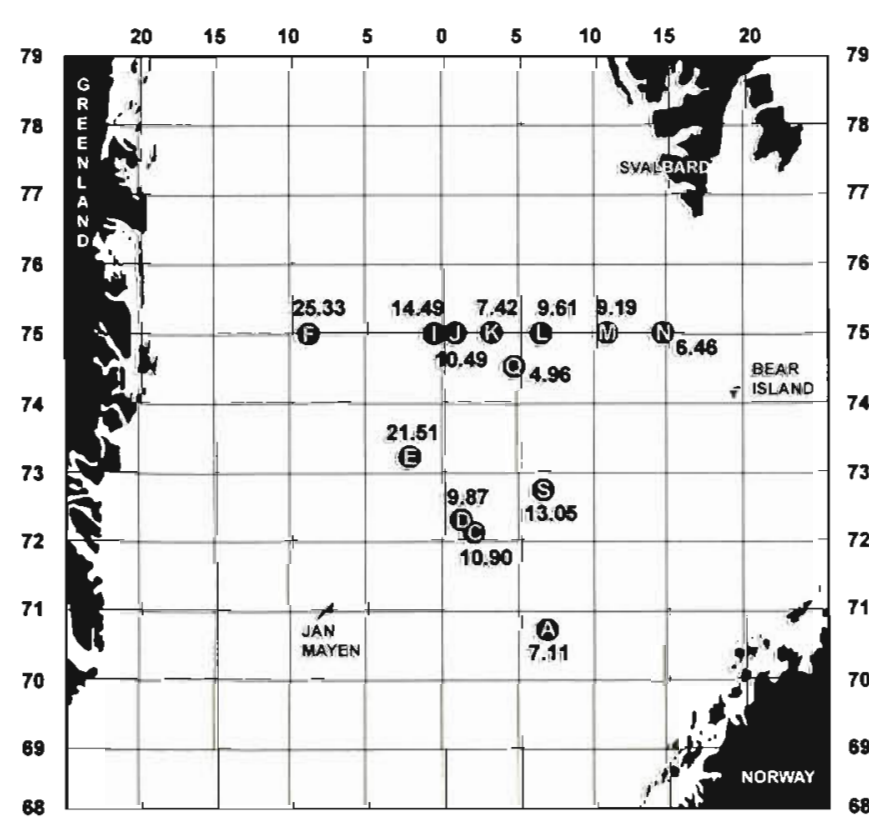

Fig. 1. Geographical distribution of bacterial production rate (mmol $\mathrm{C} \mathrm{m}^{-2} \mathrm{~d}^{-1}$ ) integrated from 0 to $50 \mathrm{~m}$ depth 


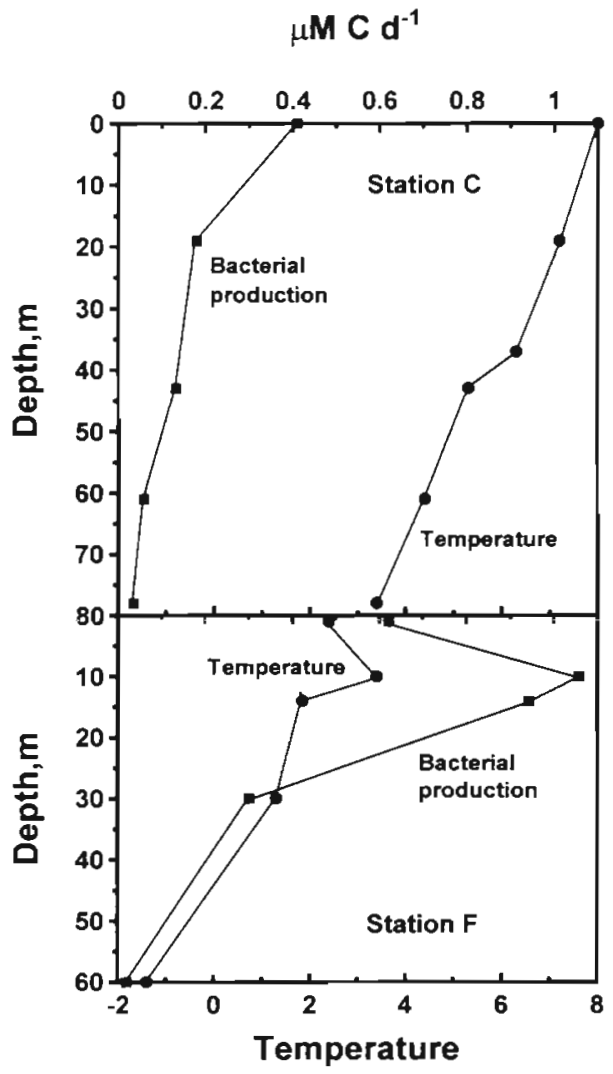

Fig. 2. Profiles of bacterial production rate and temperature at Stns $\mathrm{C}$ and $\mathrm{F}$

Table 2. Bacterial variables at the end of the growing season (stations listed in Table 1)

\begin{tabular}{|c|c|c|c|c|}
\hline & \multicolumn{4}{|c|}{ Depth interval (m) } \\
\hline & $0-50$ & $51-100$ & $101-200$ & $201-500$ \\
\hline \multicolumn{5}{|c|}{ Average bacterial production $\left(\mu \mathrm{M} \mathrm{C} \mathrm{d}^{-1}\right)$} \\
\hline Average & 0.262 & 0.041 & 0.025 & 0.006 \\
\hline $\mathrm{SD}$ & 0.228 & 0.024 & 0.016 & 0.004 \\
\hline Min. & 0.0204 & 0.0155 & 0.0019 & 0.0011 \\
\hline Max. & 1.057 & 0.080 & 0.051 & 0.012 \\
\hline $\begin{array}{l}\text { No. of measure- } \\
\text { ments }\end{array}$ & 64 & 13 & 7 & 8 \\
\hline \multicolumn{5}{|c|}{ Average bacterial total counts (cells $\mathrm{ml}^{-1}$ ) } \\
\hline Average & $1.1 \times 10^{6}$ & $5.9 \times 10^{5}$ & $3.6 \times 10^{5}$ & $1.9 \times 10^{5}$ \\
\hline $\mathrm{SD}$ & $6.9 \times 10^{5}$ & $2.1 \times 10^{5}$ & $7.8 \times 10^{5}$ & $8.4 \times 10^{4}$ \\
\hline Min. & $9.7 \times 10^{4}$ & $2.8 \times 10^{5}$ & $2.4 \times 10^{5}$ & $9.9 \times 10^{4}$ \\
\hline Max. & $2.8 \times 10^{6}$ & $1.1 \times 10^{6}$ & $4.7 \times 10^{5}$ & $3.5 \times 10^{5}$ \\
\hline $\begin{array}{l}\text { No. of measure- } \\
\text { ments }\end{array}$ & 52 & 13 & 7 & 7 \\
\hline \multicolumn{5}{|c|}{ Average bacterial growth rate $\left(\mathrm{d}^{-1}\right)$} \\
\hline Average & 0.68 & 0.14 & 0.14 & 0.07 \\
\hline $\mathrm{SD}$ & 0.83 & 0.08 & 0.10 & 0.06 \\
\hline Min. & 0.074 & 0.044 & 0.016 & 0.010 \\
\hline Max. & 4.94 & 0.28 & 0.29 & 0.18 \\
\hline $\begin{array}{l}\text { No. of measure- } \\
\text { ments }\end{array}$ & 52 & 13 & 7 & 7 \\
\hline
\end{tabular}

Aagaard 1981). Fig. 2 shows the profile of bacterial production rate and temperature at Stn C.

At the Arctic domain Stns $E$ and $F$, with surface temperatures around $2^{\circ} \mathrm{C}$, bacterial production in the upper $50 \mathrm{~m}$ was 21.5 and $25.5 \mathrm{mmol} \mathrm{C} \mathrm{m}^{-2} \mathrm{~d}^{-1}$ respectively (Fig. 1). The location where the highest bacterial production was measured at Stn F, and the profile of bacterial production rate is shown in Fig. 2. This station was located close to the edge of the sea ice off the Greenland coast. Drift-ice was also observed in the vicinity of Stn E, where the second highest bacterial production was measured. As the expedition moved eastwards along $75^{\circ} \mathrm{N}$, the bacterial production rate generally decreased, with the exception of Stn K (and Stn Q situated $84 \mathrm{~km}$ south-east of Stn K), where bacterial production was in the iower part of the range observed (Fig. 1). At Stns I, $J$ and $K$ the temperature at the surface $(5$ to $10 \mathrm{~m}$ depth) was $4.5^{\circ} \mathrm{C}$, and from $20 \mathrm{~m}$ depth temperatures were below $0^{\circ} \mathrm{C}$. Stns $\mathrm{M}$ to $\mathrm{S}$ had warm surface waters, 7 to $8^{\circ} \mathrm{C}$, and salinities above $34.9 \mathrm{PSU}$, which is characteristic of the Atlantic domain.

From the distribution of bacterial production rate in the upper $50 \mathrm{~m}$, it can be concluded that the Arctic domain water at this time of the year supported higher bacterial production than the Atlantic domain water. The highest production rates were found at the stations with the coldest surface water, and there was very low correlation between bacterial production rate and temperature in the whole data set (correlation coefficient $0.17, \mathrm{n}=92$ ).

Most of the bacterial production took place in the upper $50 \mathrm{~m}$ of the water column (Table 2). The average bacterial production rate between 0 and $50 \mathrm{~m}$ depth was about 10-fold higher than in the 100 to $200 \mathrm{~m}$ interval. Integration of the average production gave a rate of $13.1 \mathrm{mmol} \mathrm{C} \mathrm{m} \mathrm{Cd}^{-1}$ in the 0 to $50 \mathrm{~m}$ interval, and $19.1 \mathrm{mmol} \mathrm{C} \mathrm{m}^{-2} \mathrm{~d}^{-1}$ in the 0 to $500 \mathrm{~m}$ interval (data in Table 2). The total counts of bacteria were also highest in the surface interval, consequently the average bacterial growth rates showed a similar distribution (Table 2). High specific growth rates with generation times of less than a day were found in several samples (Table 2). High growth rates were also observed in waters with temperatures below $0^{\circ} \mathrm{C}$, for example a growth rate of 0.31 , which corresponds to a generation time of $2 \mathrm{~d}$ at $-1.3^{\circ} \mathrm{C}$ at $50 \mathrm{~m}$ depth at Stn $\mathrm{J}$.

One aim of the present investigation was to estimate the amount of organic carbon that had accumulated in the productive season. To establish a back- 
Table 3. TOC ( $\mu \mathrm{MC}$ ) at the end of the growing season (stations listed in Table 1)

\begin{tabular}{|lrrrrc|}
\hline $\begin{array}{l}\text { Depth } \\
\text { interval }(\mathrm{m})\end{array}$ & Average & SD & Min. & Max. & $\begin{array}{c}\text { No. of } \\
\text { measurements }\end{array}$ \\
\hline $0-50$ & 80.71 & 11.53 & 53.50 & 116.94 & 82 \\
$51-100$ & 66.86 & 9.18 & 52.61 & 85.23 & 30 \\
$101-200$ & 67.61 & 9.55 & 48.79 & 83.55 & 22 \\
$201-500$ & 66.56 & 7.05 & 55.50 & 79.93 & 29 \\
$501-1000$ & 66.55 & 8.55 & 52.05 & 90.94 & 14 \\
1001 and below & 55.56 & 7.35 & 49.28 & 69.58 & 9 \\
\hline
\end{tabular}

ground for this estimate, winter profiles were analyzed for TOC. The average from all depths in winter was $55.8 \mu \mathrm{M} \mathrm{C}(\mathrm{SD}=7 \mu \mathrm{M} \mathrm{C}, \mathrm{n}=64$ ), whereas the average from $1000 \mathrm{~m}$ depth and below was $54.9 \mu \mathrm{MC}(\mathrm{SD}=7 \mu \mathrm{M}$ $\mathrm{C}, \mathrm{n}=32$ ). The average deep water value is slightly higher than reported by Hansell \& Carlson (1998b) from the same area. Their average from 10 samples was $48.8 \mu \mathrm{M} \mathrm{C}$, and the difference may stem from a difference in background subtraction procedures. During the summer cruise, only Stn B was sampled for deep water TOC, and the average from below $1000 \mathrm{~m}$ depth was very similar to the observed winter value (Table 3 ). All averages from above $1000 \mathrm{~m}$ depth at the end of the productive season were higher than these background values (Table 3). The highest average was found in the surface layer. In the interval from 51 to $1000 \mathrm{~m}$, the average concentrations were between 10.75 and $12.06 \mu \mathrm{M} \mathrm{C}$ above the winter background of $55.8 \mu \mathrm{M} \mathrm{C}$ (Table 3 ).

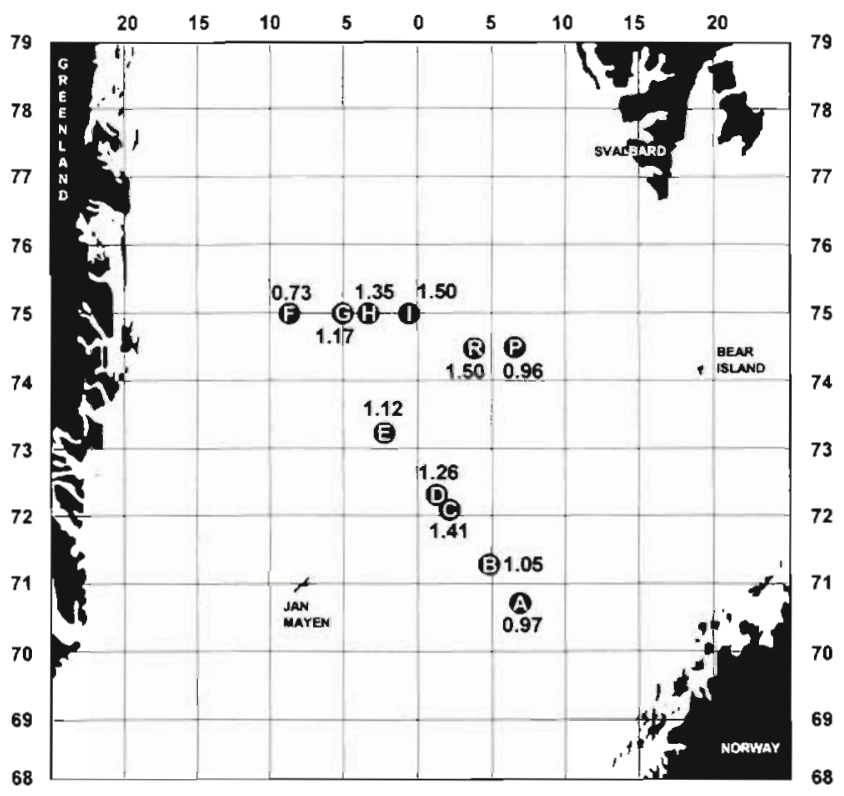

Fig. 3. Geographical distribution of transient TOC $\left(\mathrm{mol} \mathrm{C} \mathrm{m}^{-2}\right)$ integrated from 0 to $50 \mathrm{~m}$ depth
From the individual profiles, transient organic material was calculated by subtracting the average winter value of $55.8 \mu \mathrm{M} \mathrm{C}$ from each determination. The geographical distribution of the amount of transient TOC in the 0 to $50 \mathrm{~m}$ interval is shown in Fig. 3. There are no systematic differences in the amount of transient TOC between the Arctic domain stations and the Atlantic domain stations. At Stn F, where the highest bacterial production rate in the surface layer was measured, the lowest amount of transient TOC was found. Stns I and R had the highest transient TOC; Stn I had bacterial production $25 \%$ above average, and $S t n R$ was located very close to Stn $\mathrm{Q}$, which had the lowest integrated bacterial production in the 0 to $50 \mathrm{~m}$ depth interval. When individual bacterial rates are displayed versus TOC (Fig. 4), it is clearly demonstrated that TOC and bacterial production rates are correlated (correlation coefficient $=0.63$, $\mathrm{n}=35$ ).

Assuming a constant growth yield, heterotrophic turnover of the transient TOC can be calculated from the bacterial production rates. Table 4 shows turnover of transient TOC in the upper $50 \mathrm{~m}$ from the stations where both bacterial production and TOC were measured. The average turnover was $37 \mathrm{~d}$. Stn F, with highest bacterial production and lowest transient TOC, had a very short turnover of $8 \mathrm{~d}$. The longest turnover was close to $3 \mathrm{mo}$. Similar calculations can be performed for the lower parts of the water. Based on the averages given in Tables $2 \& 3$, at least the order of

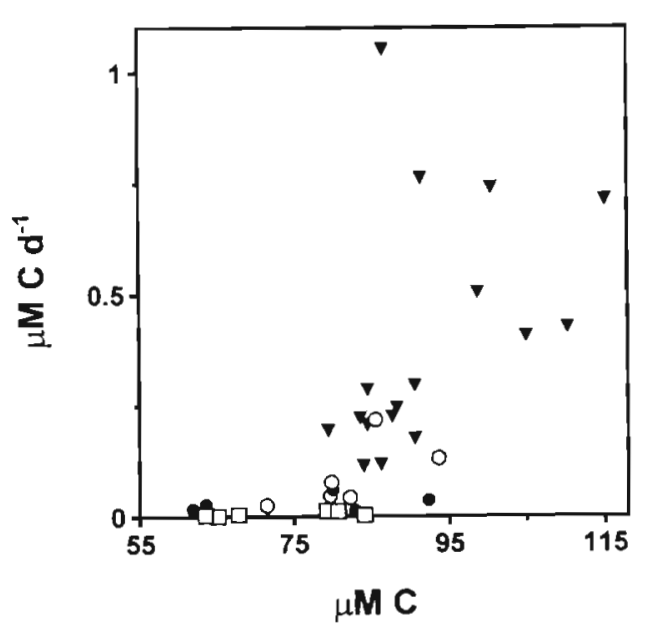

Fig. 4. Bacterial production rate versus TOC at the end of the growing season in the Greenland Sea 1996. ( $)$ ( $0-30 \mathrm{~m}_{\text {i }}$ (o) 31-50 $\mathrm{m}_{\mathrm{i}}$ (a) $51-100 \mathrm{~m}_{\text {; }}(\bullet) 101-500 \mathrm{~m}$ 
Table 4. Turnover of transient TOC in the 0 to $50 \mathrm{~m}$ depth interval. Consumption of TOC was calculated from bacterial production using a growth yield of $30 \%$

\begin{tabular}{|c|c|c|}
\hline Date; position & Stn & Turnover (d) \\
\hline Jul $22 ; 70^{\circ} 45.04^{\prime} \mathrm{N}, 07^{\circ} 00.15^{\prime} \mathrm{E}$ & A & 40.9 \\
\hline Jul $23_{i} 72^{\circ} 04.68^{\prime} \mathrm{N}, 02^{\circ} 14.75^{\prime} \mathrm{E}$ & $\mathrm{C}$ & 37.7 \\
\hline Jul $23 ; 72^{\circ} 23.80^{\prime} \mathrm{N}, 01^{\circ} 08.69^{\prime} \mathrm{E}$ & D & 37.1 \\
\hline Jul $24 ; 73^{\circ} 26.21^{\prime} \mathrm{N}, 02^{\circ} 13.14^{\prime} \mathrm{W}$ & E & 15.0 \\
\hline Jul $25 ; 74^{\circ} 59.54^{\prime} \mathrm{N}, 08^{\circ} 13.65^{\prime} \mathrm{W}$ & $\mathrm{F}$ & 8.1 \\
\hline Jul $26 ; 74^{\circ} 59.99^{\prime} \mathrm{N}, 00^{\circ} 08.79^{\prime} \mathrm{W}$ & I & 30.2 \\
\hline Aug $1 ; 74^{\circ} 30.07^{\prime} \mathrm{N}, 03^{\circ} 55.74^{\prime} \mathrm{E}$ & $\mathrm{R}^{\mathrm{a}}$ & $90.9^{\mathrm{a}}$ \\
\hline \multicolumn{3}{|c|}{ a Bacterial production rates from Stn Q } \\
\hline
\end{tabular}

magnitude of these turnovers can be suggested (Table 5). Due to low bacterial activity the turnover below $50 \mathrm{~m}$ depth is moderate, and the estimate approaches 2 yr in the 500 to $1000 \mathrm{~m}$ interval.

\section{DISCUSSION}

The most striking result from the measurements of bacterial production rates was that integrated values from the Greenland Sea Arctic domain was higher than the values from the neighborhood in the Atlantic domain (Fig. 1). Whether or not this production is fuelled by higher primary production in the Arctic domain is unknown; however, there have been reported phytoplankton blooms of considerable intensity in the Northern Greenland Sea (Smith et al. 1997). In this region, blooms of Phaeocystis spp. are common, and this species produces copious amounts of extracellular, carbohydrate-rich mucilage, which may be suspected to enrich the prevalent DOC pool. However, the quantitative importance of such blooms for the region as a whole awaits further study. The presence of drift ice in the Greenland Sea has been suspected to enhance primary production locally; however, studies of

Table 5. Average depth profile of the turnover of transient TOC, based on averages of TOC from Table 3 and bacterial production rates from Table 2. Consumption was calculated from bacterial production using a growth yield of $30 \%$. nd: no data

\begin{tabular}{|lcccc|}
\hline $\begin{array}{l}\text { Depth } \\
\text { interval } \\
(\mathrm{m})\end{array}$ & $\begin{array}{c}\text { Transient } \\
\text { TOC } \\
(\mu \mathrm{M} \mathrm{C})\end{array}$ & $\begin{array}{c}\text { Bacterial } \\
\text { production } \\
\left(\mu \mathrm{M} \mathrm{C} \mathrm{d}^{-1}\right)\end{array}$ & $\begin{array}{c}\text { Bacterial C } \\
\text { consumption } \\
\left(\mu \mathrm{M} \mathrm{C} \mathrm{d}^{-1}\right)\end{array}$ & $\begin{array}{c}\text { Transient TOC } \\
\text { turnover } \\
(\mathrm{d})\end{array}$ \\
\hline $0-50$ & 24.91 & 0.262 & 0.873 & 28.5 \\
$51-100$ & 11.06 & 0.041 & 0.137 & 80.9 \\
$101-200$ & 11.81 & 0.025 & 0.083 & 141.7 \\
$201-500$ & 10.76 & 0.006 & 0.020 & 538.0 \\
$501-1000$ & 10.75 & nd & & \\
\hline
\end{tabular}

primary production in east water polynya has demonstrated this effect only to result in moderately high new primary production (Yager et al. 1995. Smith et al. 1997).

The difference in bacterial production may also be a consequence of different timing of the heterotrophic phases following phytoplankton blooms (Sorokin 1977). Low production and high TOC may represent an early stage in the development of a heterotrophic community mineralizing $\mathrm{DOC}$, and high production combined with low TOC may represent a late phase community, well developed but close to the time when resources will be depleted. At Stn F, the turnover of transient TOC was estimated to be only $8 \mathrm{~d}$, and in this situation the latter scenario presumably occurs. Estimates of new primary production of the area are in the range of 29 to $125 \mathrm{mmol} \mathrm{C} \mathrm{m} \mathrm{d}^{-1}$, with the high values occurring in the spring bloom (Noji et al. 1999). Legendre et al. (1993) measured primary production in June along $75^{\circ} \mathrm{N}$ from within the ice belt in the west to $15^{\circ} \mathrm{E}$. They found the lowest primary production in the Arctic domain, with an average of $33.8 \mathrm{mmol} \mathrm{C} \mathrm{m}^{-2} \mathrm{~d}^{-1}$. Values from the Arctic frontal zone and the Atlantic domain averaged $57.3 \mathrm{mmol} \mathrm{C} \mathrm{m}^{-2} \mathrm{~d}^{-1}$. The production during our cruise was presumably lower because the weather was overcast or there was heavy fog. At Stn F, if it is assumed that primary production rates were equal or lower than those found by Legendre et al. (1993), it is unlikely that bacterial production rates as high as $26 \mathrm{mmol} \mathrm{C} \mathrm{m} \mathrm{m}^{-2} \mathrm{~d}^{-1}$ could be sustained for any length of time, so the situation observed was presumably close to the end of a heterotrophic bloom. In the North Atlantic water, nutrient depletion may slow down the heterotrophic processes, and these waters may have been observed in an earlier phase of the development of the heterotrophic population involved in the degradation of transient TOC. Modelling based on data of transient $D O C$ and nutrients at $66^{\circ} \mathrm{N}, 2^{\circ} \mathrm{E}$ in the Norwegian Sea suggested that transient DOC at this location has low contents of $\mathrm{N}$ and $\mathrm{P}$ (Broström 1998), and $N$ and $P$ deficiency may limit heterotrophic degradation of this material (Thingstad et al. 1997).

In the upper $50 \mathrm{~m}$ of the water column, bacterial production rate aver-

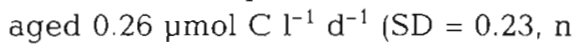
$=64$ ). In a review of open ocean bacterial production rates, Ducklow \& Carlson (1992) cited values for a large selection of locations and $\mathrm{N}$. Atlantic bacterial production at $59^{\circ} \mathrm{N}$ was estimated in the range of 0.5 to $0.58 \mu \mathrm{mol}$ $\mathrm{C}^{-1} \mathrm{~d}^{-1}$. The average values from our 
study area are only slightly lower. In the Chukchi Sea, at the end of the growing season, bacterial production rates have been estimated at approximately $1 \mathrm{mmol} C$ $\mathrm{m}^{-2} \mathrm{~d}^{-1}$ from ${ }^{14} \mathrm{C}$-leucine incorporation rates (Cota et al. 1996). Wheeler et al. (1996) reported DOC and bacterial production rate from a transect over the Polar Sea at the same time of year as the present study, and at latitudes between 70 and $75^{\circ} \mathrm{N}$ the average bacterial integral in the euphotic zone averaged $5.8 \mathrm{mmol} \mathrm{C} \mathrm{m} \mathrm{m}^{-2} \mathrm{~d}^{-1}$. Compared to these rates, our westernmost stations in the Greenland Sea had considerably higher bacterial production, and the mean of all stations was more than twice the estimate from similar latitudes in the Polar Sea (Wheeler et al. 1996, Rich et al. 1997).

The temperatures in the samples where bacterial production was measured ranged from -1.5 to $8^{\circ} \mathrm{C}$, and the system used as a thermostat of these samples during incubation provided prefixed temperatures through this range. This proved to be a very convenient arrangement, and representative profiles of samples from each station could easily be incubated at their respective in situ temperatures. The highest value of bacterial production integrated over 0 to $50 \mathrm{~m}$ depth was found close to the ice edge in Greenland Sea water with temperatures below $3^{\circ} \mathrm{C}$. There are no trends in the material to suggest that low temperatures inhibited the development of an active heterotrophic flora. Both depth and TOC, which are associated with the amount of substrate available for the bacteria, were correlated with bacterial production, whereas temperature was not.

The bacterial total counts reported were at the high end of normal counts from oligotrophic waters (e.g. Ducklow \& Carlson 1992). It should be noted that DAPI preparations were made immediately after samples had been fixed, because storage of fixed samples may lead to underestimates of total counts (Turley \& Hughes 1992). I have tested the effect of storage in a set of samples collected in the Weddell Sea and found that samples stored for 3 mo before filtering and staining gave a $50 \%$ reduction compared to preparations stained immediately after fixation (Børsheim unpubl.). The average bacterial growth rates, which were calculated from production rates and total counts, were also high (Table 2 ).

If it is assumed that bacteria have a constant growth yield, consumption of organic material can be estimated from production rates. Calculations based on a growth yield of 0.3 show that bacterial consumption is able to mineralize the transient TOC present in the upper part of the water column within weeks (Table 4). Using a very similar procedure Wheeler et al. (1996) reported a turnover of transient DOC of $47 \mathrm{~d}$ in the area between 70 and $75^{\circ} \mathrm{N}$ in the Polar Ocean, which is comparable to the mean of the estimates of $37 \mathrm{~d}$ of the 0 to $50 \mathrm{~m}$ depth interval in the present study (Table 4). The assumption of a constant growth yield is not necessarily justified (del Giorgio \& Cole 1998), and the actual turnover may be influenced by variations in growth yield. The growth yield of 0.3 used for calculating the turnover in Tables $4 \& 5$ is lower than the commonly used value of 0.5 , but experiments with growth on natural oceanic DOC have indicated yields in the lower part of the observed range, frequently even lower than 0.3 (Ducklow \& Carlson 1992, del Giorgio \& Cole 1998). A better estimate of turnover will have to await improvements in the estimate of growth yield.

In the upper $50 \mathrm{~m}$ the average transient TOC was $1.18 \mathrm{~mol} \mathrm{C} \mathrm{m}^{-2}$. This is lower than the peak annual amount estimated from monthly profiles at $66^{\circ} \mathrm{N}, 2^{\circ} \mathrm{E}$ in the Norwegian Sea (Børsheim \& Myklestad 1997). However, from a single visit we cannot determine if the peak is reached or not, but it is reasonable to believe that the sampling occurred somewhat before the culmination of the annual accumulation of transient TOC. In 1991 and 1992 the accumulation at $66^{\circ} \mathrm{N}, 2^{\circ} \mathrm{E}$ culminated in the beginning of September, and since the eastern stations in the present study are fed by water originating from the south, it may be expected that observations are from before and not at or after culmination of the annual accumulation of transient TOC. However, at the westernmost stations, where bacterial production rate indicated a turnover of transient TOC of $8 d$, it is more likely that the culmination is closer.

A large part of the transient TOC was found below the euphotic zone, where mineralization is much slower than in the upper 0 to $50 \mathrm{~m}$. Between 200 and $500 \mathrm{~m}$ depth the average bacterial production rate was $0.006 \mu \mathrm{M} \mathrm{C} \mathrm{d}^{-1}$, which is comparable to values in the same depth interval in the North Pacific gyre (Cho \& Azam 1988). In the water column between 50 and $1000 \mathrm{~m}$ depth, an excess beween 10.75 and $11.8 \mu \mathrm{M} \mathrm{C}$ was found compared to the winter profiles (Table 5). This moderate elevation in concentration represented a large amount of organic material due to the large depth interval in which it was present, and the turnover between 200 and $500 \mathrm{~m}$ depth approached 2 yr (Table 5). However, if it is assumed that transient TOC at these depths has a longer history of diagenesis than at the surface, growth yields are expected to be lower. Growth yields below 0.1 have been measured on matured DOC (del Giorgio \& Cole 1998), and if such low growth yields predominate at depths below $200 \mathrm{~m}$, the turnover is proportionally overestimated in Table 5 .

The major sources of substrate supporting bacterial production below the euphotic zone is DOC solubilized from sedimenting particles, and DOC transferred from the euphotic zone by mixing and diffusion processes (Lefèvre et al. 1996). Sedimentation rates have previously been measured at approximately $0.8 \mathrm{mmol} \mathrm{m}^{-2}$ 
$\mathrm{d}^{-1}$ in the Greenland Sea at $200 \mathrm{~m}$ depth in July/ August, and about $0.17 \mathrm{~mol} \mathrm{C} \mathrm{m} \mathrm{Cr}^{-2}$ (Noji et al. 1999). The bacterial production rate between 200 and $500 \mathrm{~m}$ depth was on average $0.06 \mu \mathrm{M} \mathrm{C} \mathrm{d}^{-1}$, which cor-

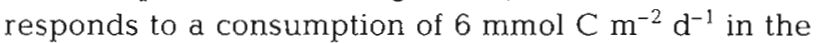
200 to $500 \mathrm{~m}$ interval at a growth yield of 0.3 . These numbers suggest that transport by sedimentation is too low to support the bacterial production below the euphotic zone. As discussed in more detail by Lefèvre et al. (1996), export of DOC from the euphotic zone is likely to dominate the support of substrate for heterotrophic bacterial production below the euphotic zone. They estimated respiration in the northwestern Mediterranean Sea in the 200 to $1000 \mathrm{~m}$ interval at $1.15 \mathrm{~mol} \mathrm{C} \mathrm{m}^{-2} \mathrm{yr}^{-1}$, and export by sedimentation at $200 \mathrm{~m}$ deptin at only $0.33 \mathrm{~mol} \mathrm{C} \mathrm{m}{ }^{-2} \mathrm{yr}^{-1}$. The export of DOC from the euphotic zone as estimated by CopinMontégut \& Avril (1993) was hypothesized to contribute the major part of the substrate for consumption below the euphotic zone. There is a striking similarity between the budgets from the Mediterranean Sea and the Greenland Sea, and the implicated role of DOC may well prove general for open ocean waters.

In surface waters of the Greenland Sea, the concentration of total inorganic carbon (DIC) decreased by approximately $100 \mu \mathrm{M} \mathrm{C}$ in the growing season (Anderson et al. 1998, Miller et al. 1999). Primary production transfers DIC into particulate organic material, and sedimentation of organic particles in the Greenland Sea has been shown to be approximately $0.17 \mathrm{~mol}$ $\mathrm{C} \mathrm{m}^{-2} \mathrm{yr}^{-1}$ (Noji et al. 1999), out of a primary production of $4.75 \mathrm{~mol} \mathrm{C} \mathrm{m} \mathrm{C}^{-2} \mathrm{yr}^{-1}$. This sedimentation rate contributes only marginally to the continuation of a gradient favouring diffusion of $\mathrm{CO}_{2}$ into the ocean. However, transient DOC represents a large quantity of material that may be advected vertically, especially during the autumn turnover. Due to the large amounts that are present at the end of the growing season it is reasonable to conclude that transient DOC can play an important role as part of the biological pump of carbon out of surface waters, a role which has previously been attributed mainly to sedimenting particulate material. The allocation of transient DOC may constitute an important but still far from precisely quantitated part of the biological pump of carbon from the surface to deeper water in the Greenland Sea.

Acknowledgements. This work was supported by the Commission of the European Communities under contracts MAS3CT95-0015 and MAS2-CT93-0057 of the MAST-programme, and by NFR 127349/122. I thank Fransisco Rey and Thomas Noji for cooperation on the RV 'Johan Hjort' cruise in 1996, Lisa Miller, Truls Johannessen, Ingunn Skjelvan and Thomas Noji for samples from other cruises, and Sverre M. Myklestad for discussions during the project.

\section{LITERATURE CITED}

AlvarezSalgedo XA, Doval MD, Perez EF (1999) Dissolved organic matter in shelf waters off Ria de Vigo (NW Iberian upwelling system). J Mar Syst 4:383-394

Anderson LG, Olsson K, Chierici M (1998) A carbon budget for the Arctic Ocean. Global Biogeochem Cycles 12: $455-465$

Anderson LG, Chierici M, Fogelquist E, Johannessen T (2000) Flux of anthropogenic carbon into the deep Greenland Sea. J Geophys Res (in press)

Børsheim KY (1990) Bacterial biomass and production rate in the Gulf Stream front regions. Deep-Sea Res 37: $1297-1309$

Børsheim KY, Myklestad SM (1997) Dynamics of DOC in the Norwegian Sea inferred from monthly profiles collected during three years at $66^{\circ} \mathrm{N}, 2^{\circ} \mathrm{E}$. Deep-Sea Res 37: $1297-1309$

Børsheim KY, Myklestad SM, Sneli JA (1999) Monthly profiles of DOC, mono- and polysaccharides in the Trondheimsfjord (Norway) during two years. Mar Chem 63: $255-272$

Broecker WS, Peng TH (1992) Interhemispheric transport of carbon dioxide by oceanic circulation. Nature 356: $587-589$

Broström G (1998) A note on the $\mathrm{C} / \mathrm{N}$ and $\mathrm{P} / \mathrm{N}$ ratio of the biological production in the Nordic seas. Tellus 50B:93-109

Carlson CA, Ducklow HW (1996) Growth of bacterioplankton and consumption of dissolved organic carbon in the SaIgasso Sea. Aquat Microb Ecol 10:69-85

Carlson CA, Ducklow HW, Michaels AF (1994) Annual flux of dissolved organic carbon from the euphotic zone in the northwestern Sargasso Sea. Nature 371:405-408

Cho B C, Azam F (1988) Major role of bacteria in biogeochemical fluxes in the ocean's interior. Nature 332: $441-443$

Copin-Montégut G, Avril B (1993) Vertical distribution of temporal variation of dissolved organic carbon in the North-Western Mediterranean Sea. Deep-Sea Res 40: 1963-1972

Cota GF, Pomeroy LR, Harrison WG, Jones EP, Peters F, Sheldon WM Jr, Weingartner TR (1996) Nutrients, primary production and microbial heterotrophy in the southeastern Chukchi Sea: Arctic summer nutrient depletion and heterotrophy. Mar Ecol Prog Ser 135:247-258

del Giorgio PA, Cole JJ (1998) Bacterial growth efficiency in natural aquatic systems. Annu Rev Ecol Syst 29:503-541

Ducklow HW, Carlson CA (1992) Oceanic bacterial production. Adv Microb Ecol 12:113-181

Fuhrman JA, Azam F (1980) Bacterioplankton production estimates for coastal waters of British Columbia, Antarctica and California. Appl Environ Microbiol 39:1085-1095

Fuhrman JA, Azam F (1982) Thymidine incorporation as a measure of heterotrophic bacterioplankton production in marine surface waters: evaluation and field results. Mar Biol 66:109-120

Hansell DA, Carlson CA (1998a) Net community production of dissolved organic carbon. Global Biogeochem Cycles 3 : $443-453$

Hansell DA, Carlson CA (1998b) Deep-ocean gradients in the concentration of dissolved organic carbon. Nature 395: 263-266

Hansell DA, Carlson CA, Bates NR, Poisson A (1997) Horizontal and vertical removal of organic carbon in the equatorial Pacific Ocean: a mass balance assessment. Deep-Sea Res II 44:2115-2130

Lefèvre D, Denis M, Lambert CE, Miquel JC (1996) Is DOC 
the main source of organic remineralization in the ocean water column? J Mar Syst 7:281-291

Legendre L, Gosselin M, Hirche HG, Kattner G, Rosenberg G (1993) Environmental control and potential fate of sizefractionated phytoplankton production in the Greenland Sea $\left(75^{\circ} \mathrm{N}\right)$. Mar Ecol Prog Ser 98:297-313

Miller L, Chierici M, Johannesen T, Noji TT, Rey F, Skjelvan I (1999) Seasonal dissolved inorganic carbon distributions in the Greenland Sea and implications for atmospheric $\mathrm{CO}_{2}$ exchange. Deep-Sea Res II 46:1473-1496

Noji TT, Rey F, Miller LA, Børsheim KY, Urban-Rich J (1999) Fate of biogenic carbon in the upper $200 \mathrm{~m}$ of the Central Greenland Sea. Deep-Sea Res II 46:1497-1509

Porter KG, Feig YS (1980) The use of DAPI for identifying and counting aquatic microflora. Limnol Oceanogr 25:943-948

Rich J, Gosselin M, Sherr E, Sherr B, Kirchman DL (1997) High bacterial production, uptake and concentrations of dissolved organic matter in the Central Arctic Ocean. Deep-Sea Res II 44:1645-1663

Sharp JH (1997) Marine dissolved organic carbon: are the older values correct? Mar Chem 56:256-277

Sharp JH, Benner, R, Bennett L, Carlson CA, Dow R, Fitzwater SE (1993) Re-evaluation of high temperature combustion and chemical oxidation measurements of dissolved organic carbon in seawater. Limnol Oceanogr 38: 1774-1782

Siegenthaler U, Sarmiento JL (1993) Atmospheric carbon dioxide and the ocean. Nature 365:119-125

Smith WO, Gosselin $M$, Legendre L, Wallace D, Daly $K$, Kattner G (1997) New production in the Northeast Water

Editorial responsibility: Karin Lochte,

Rostock, Germany
Polynya, 1993. J Mar Syst 10:199-209

Sorokin YuI (1977) The heterotrophic phase of plankton succession in the Japan Sea. Mar Biol 41:107-117

Suzuki Y, Tanoue E, Ito H (1992) A high temperature catalytic method for the determination of dissolved organic carbon in seawater: analysis improvement. Deep-Sea Res 19: $185-198$

Swift JF, Aagaard K (1981) Seasonal transitions and water formation in the Icealand and Greenland Seas. Deep-Sea Res 28:1107-1129

Thingstad TF, Hagström $\AA$, Rassoulzadegan F (1997) Accumulation of degradable DOC in surface waters: is it caused by a malfunctioning microbial loop? Limnol Oceanogr 42:398-404

Turley CM, Hughes DJ (1992) Effects of storage on direct estimates of bacterial numbers of preserved samples. DeepSea Res 39:375-394

Wheeler PA, Gosselin M, Sherr E, Thibault D, Kirchman, DL, Benner R, Whitledge TE (1996) Active cycling of organic carbon in the central Arctic Ocean. Nature 380:697-699

Williams PJleB (1995) Evidence for the seasonal accumulation of carbon-rich dissolved organic matter, its scale in comparison with changes in particulate material and the consequental effect on net $\mathrm{C} / \mathrm{N}$ assimilation ratios. Mar $\mathrm{Chem}$ $51: 17-29$

Yager PL, Wallace DWR, Johnson KM, Smith WO, Minnet PJ, Deming JW (1995) The Northeast Water Polynya as an atmospheric sink: a seasonal hypothesis. J Geophys Res $100: 4389-4398$

Submitted: July 27, 1999; Accepted: December 20, 1999 Proofs received from author(s): February 23, 2000 